\title{
ANALISIS TEKNIK DAN KUALITAS TERJEMAHAN ISTILAH BUDAYA DALAM KUMPULAN ABSTRAK HASIL PENELITIAN SEKOLAH TINGGI SENI INDONESIA (STSI) SURAKARTA
}

\author{
Dewi Nurnani, M.R. Nababan, Djatmika \\ Universitas Sebelas Maret \\ dewinur09@gmail.com
}

\begin{abstract}
The aims of the study are to ascertain (1) translation techniques applied in Kumpulan Abstrak Hasil Penelitian 1990-1991 Sekolah Tinggi Seni Indonesia (STSI) Surakarta; (2) the character of translation techniques applied in the translation of Kumpulan Abstrak Hasil Penelitian 1990-1991 Sekolah Tinggi Seni Indonesia (STSI) Surakarta ; and (3) levels of translation accuracy and acceptability and their relationships with the techniques as well as character of translation techniques. This is a descriptive qualitative research with an embedded-case study in translation which uses purposive sampling technique. The sources of data for this research method comprise of a document of Kumpulan Abstrak Hasil Penelitian 1990-1991 Sekolah Tinggi Seni Indonesia (STSI) Surakarta and informants. The research data consists of words, phrases, and clauses in Kumpulan Abstrak Hasil Penelitian (KAHP) 1990-1991 Sekolah Tinggi Seni Indonesia (STSI) Surakarta and its translation in English and the raters' statements about the accuracy and acceptability levels of translation. The research data were collected with document analysis, questionnaires, and interview. Findings of the research show the following. First, there are 13 techniques used in the translation. 5 of them are included in mandatory techniques while the optional techniques include 12 techniques. It can be seen from the findings that 4 techniques belong to mandatory as well as optional techniques. Based on the quality analysis, it can be found that there are 9 techniques positively influence the translation accuracy and 11 techniques positively influence the translation acceptability. Thus, it can be concluded that, generally, the accuracy and acceptability of the translation are included in high level.
\end{abstract}

Keywords: cultural terms, abstract, translation technique, accuracy, acceptability

\begin{abstract}
ABSTRAK
Penelitian ini bertujuan untuk mengetahui (1) teknik-teknik penerjemahan yang diterapkan dalam terjemahan istilah seni dan budaya dalam Kumpulan Abstrak Hasil Penelitian (KAHP) 1990-1991 Sekolah Tinggi Seni Indonesia (STSI) Surakarta ke dalam bahasa Inggris , (2) sifat teknik penerjemahan yang digunakan dalam terjemahan tersebut, dan (3) pengaruh teknik serta sifat teknik penerjemahan yang diterapkan terhadap tingkat keakuratan dan keberterimaan terjemahan. Penelitian ini menggunakan pendekatan deskriptif-kualitatif dalam bidang penerjemahan yang bersifat terpancang. Sumber data dalam penelitian ini adalah Kumpulan Abstrak Hasil Penelitian (KAHP) 1990-1991 Sekolah Tinggi Seni Indonesia (STSI) Surakarta dengan menggunakan teknik sampling bertujuan. Data terdiri dari kata dan frasa istilah seni dan budaya dalam KAHP 1990-1991 STSI Surakarta dan terjemahannya dan penilaian serta pernyataan informan tentang
\end{abstract}


tingkat keakuratan dan keberterimaan. Metode pengumpulan data yang digunakan dalam penelitian ini terdiri atas pengkajian dokumen, kuesioner, dan wawancara. Hasil penelitian menunjukkan adanya 13 (tigabelas) teknik penerjemahan yang digunakan penerjemah dalam terjemahan tersebut. 5 (lima) dari teknik tersebut bersifat wajib dan 12 (dua belas) teknik bersifat tidak wajib. Dari temuan tersebut juga diketahui bahwa ada 4 (empat) teknik yang bersifat wajib dan tidak wajib. Berdasarkan analisis kualitas terjemahan, 9 (sembilan) teknik penerjemahan berpengaruh positip terhadap keakuratan terjemahan dan 11 (sebelas) teknik berpengaruh positip terhadap keberterimaan terjemahan sehingga, secara umum, tingkat keakuratan dan keberterimaan terjemahan tersebut tinggi.

Kata kunci: istilah budaya, abstrak, teknik penerjemahan, keakuratan, keberterimaan

\section{PENDAHULUAN}

Bangsa Indonesia adalah bangsa yang berbudaya. Bangsa yang memiliki berbagai macam budaya dan kesenian. Budaya dan kesenian tersebut tersebar di seluruh wilayah dan kepulauan di Indonesia termasuk pulau Jawa. Di pulau Jawa, ada berbagai macam kesenian seperti seni tari Jawa, seni karawitan Jawa, dan satu yang sekarang ini sedang merambah ke manca negara yaitu wayang. Kesenian-kesenian Jawa tersebut sudah lama dikenal oleh orang-orang dari manca negara sehingga tidak mengherankan apabila beberapa dari mereka tertarik atau berminat untuk mempelajari bahkan untuk bisa berkesenian Jawa.

Dalam beberapa tahun terakhir ini tidak sedikit mahasiswa asing yang belajar kesenian Jawa baik di sanggar-sanggar maupun di perguruan tinggi seni di Indonesia seperti Institut Seni Indonesia (dahulu STSI) Surakarta maupun ISI Yogyakarta. Seperti halnya di ISI Surakarta, tidak semua mahasiswa asing yang belajar di sana bisa atau mampu berbahasa Indonesia dengan baik padahal mereka harus mengikuti perkuliahan yang semuanya menggunakan pengantar bahasa Indonesia bahkan ada beberapa mata kuliah yang menggunakan pengantar bahasa Jawa. Oleh karena itu mereka tidak mungkin sepenuhnya bergantung pada perkuliahan saja. Mereka harus mencari alternatif lain untuk memperoleh hasil yang maksimal diantaranya dengan menggali dari buku referensi yang tentu saja berbahasa Inggris atau yang lain selain bahasa Indonesia atau bahasa Jawa.

ISI Surakarta, yang pada waktu itu masih berstatus Sekolah Tinggi Seni Indonesia (STSI) Surakarta, telah berusaha untuk memenuhi kebutuhan tersebut salah 
satunya dengan menerjemahkan suatu kumpulan abstrak hasil penelitian oleh para dosen ISI Surakarta yang tentu saja berkaitan dengan semua bidang seni yang ada di ISI Surakarta yaitu seni tari, seni karawitan, seni pedalangan, dan seni rupa. Hal tersebut tertuang dalam Kumpulan Abstrak Hasil Penelitian 1990-1991 yang diterjemahkan ke dalam Collection of Research Abstracts 1990-1991. Dari terjemahan tersebut, mahasiswa asing yang sedang belajar kesenian di ISI Surakarta sedikit banyak bisa memperoleh gambaran atau informasi tentang penelitian-penelitian yang berkaitan dengan bidang mereka masing-masing sehingga nantinya mereka bisa memilih referensi mana yang sesuai untuk mereka.

Seperti yang kita ketahui bersama bahwa menerjemahkan adalah suatu pekerjaan yang tidak mudah apalagi bagi orang yang tidak memiliki kemampuan dalam bidang penerjemahan. Bahkan orang yang bisa berbahasa Inggris belum tentu bisa menerjemahkan dengan baik. Hal itu disebabkan adanya beberapa perbedaan antara kedua bahasa tersebut. Seperti yang dikatakan Sakri (Sakri, 1985:9) "...ungkapan bahasa Indonesia berbeda dengan ungkapan bahasa Inggris; setiap bahasa memiliki adatnya sendiri-sendiri dan itulah salah satu hal yang menyebabkan pekerjaan menerjemahkan tidak semudah diperkirakan orang”.

Penelitian ini hampir sama dengan penelitian-penelitian sebelumnya yang juga mengkaji tentang istilah. Perbedaannya (research gap) adalah bahwa penelitian ini menganalisis tentang istilah-istilah seni dan budaya Indonesia khususnya Jawa. Selain itu, ada perbedaan juga dalam hal bahasa sumber dan bahasa sasaran, kalau penelitian sebelumnya bahasa sumbernya bahasa Inggris dan bahasa sasarannya bahasa Indonesia, sementara penelitian ini adalah sebaliknya yaitu bahasa sumbernya bahasa Indonesia sedangkan bahasa sasarannya bahasa Inggris. Hal ini berkaitan dengan obyek yang dianalisis yaitu seni dan budaya Indonesia (Jawa).

Permasalahan dalam penelitian ini adalah (1) teknik - teknik penerjemahan apa saja yang diterapkan dalam penerjemahan istilah-istilah seni dan budaya dalam Kumpulan Abstrak Hasil Penelitian 1990-1991 (KAHP) Sekolah Tinggi Seni Indonesia (STSI) Surakarta dan terjemahannya Collection of Research Abstracts 1990-1991 (CoRA), (2) sifat dari teknik penerjemahan yang diterapkan dalam terjemahan tersebut, dan (3) dampak teknik dan sifat teknik penerjemahan yang diterapkan terhadap kualitas terjemahan yang mencakup aspek keakuratan dan keberterimaan. Peneliti tidak 
membahas tentang keterbacaan terjemahan karena pertama, waktu yang sangat terbatas; kedua, pada periode tahun pembelajaran 2015/2016 ini mahasiswa darmasiswa yang sedang belajar di Institut Seni Indonesia (ISI) Surakarta yang diharapkan bisa menjadi rater keterbacaan kurang memenuhi syarat. Mereka kurang lancar dalam berbahasa Inggris.

Dalam penelitian ini, peneliti memberi batasan yaitu pada istilah-istilah seni dan budaya yang berupa kata atau frasa yang terkandung dalam kalimat-kalimat yang terdapat dalam Kumpulan Abstrak Hasil Penelitian tersebut.

Sesuai dengan rumusan masalah yang telah dipaparkan di atas maka tujuan yang ingin dicapai peneliti dalam penelitian ini adalah: (1) mengidentifikasi dan mendeskripsikan teknik-teknik penerjemahan yang diterapkan dalam penerjemahan istilah-istilah seni dan budaya dalam KAHP, (2) menganalisis dan menjelaskan sifat dari teknik penerjemahan yang diterapkan dalam terjemahan tersebut, dan (3) menganalisis dan menjelaskan pengaruh teknik dan sifat teknik penerjemahan yang diterapkan terhadap kualitas terjemahan yang meliputi keakuratan dan keberterimaan terjemahan.

\section{TEORI DAN METODOLOGI}

Penelitian ini adalah penelitian dasar dalam bidang penerjemahan. Penelitian dasar juga sering disebut penelitian akademik atau penelitian murni yang hanya bertujuan untuk pemahaman mengenai suatu masalah yang mengarah pada manfaat teoritik dan bukan manfaat praktis (Sutopo, 2006: 135-136).

Penelitian ini berupa studi kasus dalam pengertian bahwa semua bentuk penelitian kualitatif, baik penelitian dasar maupun penelitian terapan selalu bersifat kontekstual, dan berdasarkan sifat kekhususannya tersebut, sama sekali tidak ada usaha atau pemikiran untuk melakukan generalisasi (Sutopo, 2006: 136).

Pendekatan yang digunakan dalam penelitian ini adalah kualitatif deskriptif. Hal ini dimaksudkan bahwa penelitian kualitatif selalu menyajikan temuannya dalam bentuk deskripsi kalimat yang rinci, lengkap, dan mendalam mengenai proses mengapa dan bagaimana sesuatu terjadi (Sutopo, 2006: 139).

Penelitian ini bersifat terpancang (embedded research) maksudnya adalah peneliti sudah menentukan fokus penelitian sebelum mengambil data di lapangan. Seperti yang dikatakan oleh Yin dalam Sutopo (2006: 39) bahwa penelitian terpancang 
adalah penelitian yang sudah menentukan fokus penelitiannya berupa variabel utama yang akan dikaji berdasarkan tujuan dan minat penelitinya sebelum peneliti masuk ke lapangan studinya.

Data dalam penelitian ini adalah istilah seni dan budaya Indonesia yang berupa kata atau frasa yang diambil dari dokumen Kumpulan Abstrak Hasil Penelitian 19901991 Sekolah Tinggi Seni Indonesia (STSI) Surakarta dan terjemahannya Collection of Research Abstracts 1990 - 1991. Selain itu, data juga dilengkapi informasi yang diperoleh dari informan yaitu rater melalui wawancara mendalam dan penyebaran kuesioner.

Teknik pengumpulan data yang akan digunakan dalam penelitian ini adalah mengkaji dokumen dan arsip (content analysis) atau teknik baca dan catat, kuesioner dan wawancara mendalam.

Dalam mengkaji dokumen, peneliti menggunakan teknik baca dan catat. Langkah-langkah yang akan dilakukan dalam penelitian ini adalah pertama, membaca buku teks asli yaitu Kumpulan Abstrak Hasil Penelitian 1990-1991 Sekolah Tinggi Seni Indonesia (STSI) Surakarta dan terjemahannya, Collection of Research Abstracts 19901991. Kemudian memilih dan memberi tanda teks atau kalimat yang mengandung istilah-istilah seni dan budaya Indonesia. Selanjutnya, mencatat teks atau kalimat yang mengandung istilah-istilah seni dan budaya Indonesia. Keempat, mengklasifikasi data istilah-istilah seni dan budaya Indonesia. Langkah selanjutnya, mengidentifikasi dan mendeskripsikan teknik penerjemahan yang digunakan dalam penerjemahan istilahistilah seni dan budaya dalam Kumpulan Abstrak Hasil Penelitian 1990-1991 Sekolah Tinggi Seni Indonesia (STSI) Surakarta dan terjemahannya dan terakhir, membuat penilaian terhadap data yang sudah dianalisis.

Kuesioner diperlukan dalam penelitian ini untuk memperoleh data yang berkaitan dengan kualitas terjemahan yang meliputi keakuratan, keberterimaan dan keterbacaan. Data yang berkaitan dengan keakuratan dan keberterimaan diperoleh dari para pembaca ahli (rater) sedangkan data tentang keberterimaan diperoleh dari pembaca target. Pertanyaan dalam kuesioner bersifat terbuka sehingga informan dapat menjelaskan, memberikan argumentasi atau memberikan alternatif .

Wawancara dilakukan oleh peneliti dalam rangka memperoleh kemantapan data yang telah diperoleh melalui teknik analisis dokumen dan kuesioner. Pertanyaan 
yang diberikan bersifat terbuka (open-ended) untuk mengkonfirmasi jawaban kuesioner yang diberikan sebelumnya. Hal ini dimaksudkan untuk memperoleh informasi yang lebih dalam dan lengkap dari nara sumber dan dilakukan secara tidak formal terstruktur (Sutopo, 2006: 69).

Triangulasi merupakan cara yang paling umum digunakan bagi peningkatan validitas data dalam penelitian kualitatif (Sutopo, 2006: 92). Patton dalam Sutopo (2006: 92) mengemukakan empat jenis triangulasi meliputi: triangulasi sumber atau disebut juga triangulasi data, triangulasi metode, triangulasi peneliti, dan triangulasi teori. Dalam penelitian ini, peneliti akan mengembangkan dua teknik triangulasi dari keempat triangulasi tersebut yaitu triangulasi sumber atau triangulasi data dan triangulasi metode.

Untuk menguji keabsahan atau kesahihan data, peneliti perlu melakukan pengumpulan data dari berbagai sumber. Data yang sama atau sejenis, akan lebih mantap kebenarannya apabila digali dari beberapa sumber data yang berbeda (Sutopo, 2006: 93). Dalam penelitian ini, peneliti akan menggali data dari hasil analisis dokumen (content analysis) dan dari informan yang terdiri dari rater dan pembaca target.

Teknik triangulasi metode dilakukan dengan cara mengumpulkan data sejenis dari sumber yang sama dengan menggunakan teknik atau metode pengumpulan data yang berbeda (Sutopo, 2006: 95). Berbeda dengan triangulasi sumber yang lebih menekankan sumber data yang berbeda, teknik triangulasi metode lebih menekankan metode pengumpulan data yang berbeda dari data yang sama. Dalam penelitian ini, peneliti mengumpulkan data yang sama atau sejenis dari informan melalui metode yang berbeda yaitu dengan menyebarkan kuesioner, kemudian untuk konfirmasi dan menggali informasi yang lebih mendalam peneliti melakukan wawancara mendalam dengan informan tersebut. Hal ini dimaksudkan untuk memperoleh data yang lebih sahih.

Peneliti menggunakan teknik cuplikan berkaitan dengan pemilihan dan pembatasan jumlah serta jenis dari sumber data yang akan digunakan dalam penelitian. Peneliti mengambil data dengan menggunakan teknik purposive sampling. Data yang diambil adalah data yang dianggap memiliki informasi sesuai dengan permasalahan dalam penelitian dan berdasarkan kriteria tertentu. Selain itu, peneliti juga memilih 
informan yang dianggap memiliki atau bisa memberi informasi sesuai dengan permasalahan dalam penelitian untuk menjadi sumber data.

Dalam penelitian ini peneliti menggunakan analisis isi (content analysis) berdasarkan teori penerjemahan seperti yang sudah dibahas dalam bab II, sedangkan tahapan analisisnya menggunakan teknik analisis data dari Spradley ( Sutopo, 2006: 122-127) yang meliputi: analisis domain (kawasan), analisis taksonomik, analisis komponensial dan analisis tema budaya.

Peneliti mengidentifikasi data yang berupa istilah seni dan budaya dari sumber data yaitu Kumpulan Abstrak Hasil Penelitian 1990-1991 (KAHP) Sekolah Tinggi Seni Indonesia (STSI) Surakarta dan terjemahannya Collection of Research Abstracts 1990-1991 (CoRA), misalnya:

\section{Contoh data $\quad$ Bsu: tanda suwuk \\ Bsa: suwuk signal \\ Contoh bukan data Bsu: Gathutkaca Lahir \\ Bsa: Gathutkaca Lahir}

Frasa Gathutkaca Lahir bukan merupakan data karena frasa tersebut bukan termasuk istilah seni atau budaya tetapi salah satu lakon dalam pertunjukan wayang.

Analisis taksonomik adalah analisis yang terfokus pada satu domain atau subdomain tertentu. Pada tahapan ini, data yang didapat kemudian diklasifikasikan berdasarkan teknik-teknik penerjemahan oleh Molina dan Albir (2002 : 509-511).

Tabel 1. Contoh analisis taksonomik

\begin{tabular}{|l|l|l|l|}
\hline No. Data & Bsu & Bsa & Teknik Penerjemahan \\
\hline 001. & $\begin{array}{l}\text { Garap } \\
\text { khusus }\end{array}$ & $\begin{array}{l}\text { A special kind of garap (the } \\
\text { treatment or working of the music) }\end{array}$ & Deskripsi (description) \\
\hline 002. & Empu & Great master & Generalisasi (generalization) \\
\hline
\end{tabular}

Istilah-istilah seni dan budaya tersebut diklasifikasikan berdasarkan teknik penerjemahan yang diterapkan oleh penerjemah.

Tabel 2. Contoh analisis komponensial

\begin{tabular}{|c|c|c|c|c|}
\hline \multirow{2}{*}{$\begin{array}{l}\text { No } \\
\text { data }\end{array}$} & \multirow[t]{2}{*}{ Teknik } & \multicolumn{3}{|l|}{ Kualitas } \\
\hline & & Keakuratan & Keberterimaan & Keterbacaan \\
\hline 001. & $\begin{array}{l}\text { Penerjemahan } \\
\text { deskripsi }\end{array}$ & $\begin{array}{l}\text { Akurat: } \\
\text { Kurang akurat: } \\
\text { Tidak akurat: }\end{array}$ & $\begin{array}{l}\text { Berterima: } \\
\text { Kurang berterima: } \\
\text { Tidak berterima: }\end{array}$ & $\begin{array}{l}\text { Terbaca: } \\
\text { Kurang terbaca: } \\
\text { Tidak terbaca: }\end{array}$ \\
\hline
\end{tabular}


Dari analisis komponensial diperoleh temuan bagaimana hubungan antara istilah seni dan budaya, teknik penerjemahan yang digunakan, sifat teknik yang diterapkan dengan kualitas terjemahan yang meliputi keakuratan pesan dan keberterimaan.

\section{TEMUAN DAN PEMBAHASAN}

Hasil penelitian ini menunjukkan adanya 13 teknik penerjemahan yang diterapkan oleh penerjemah dalam menerjemahkan istilah-istilah seni dan budaya dalam Kumpulan Abstrak Hasil Penelitian 1990-1991 (KAHP) Sekolah Tinggi Seni Indonesia (STSI) Surakarta ke dalam terjemahannya Collection of Research Abstracts 1990-1991 (CoRA). Teknik-teknik tersebut meliputi teknik: peminjaman murni, padanan lazim, generalisasi, addition, deskripsi, reduksi, adaptasi, deletion, amplifikasi, eksplisitasi, kalke, kreasi diskursif, dan peminjaman alamiah.

Berikut ini adalah urutan penerapan teknik penerjemahan oleh penerjemah dalam terjemahan istilah seni dan budaya: teknik peminjaman murni diterapkan 81 kali, teknik padanan lazim 30 kali penerapan, teknik generalisasi menempati urutan ketiga yaitu 16 kali, teknik addition diterapkan 14 kali, teknik deskripsi 13 kali, teknik reduksi diterapkan 5 kali, teknik adaptasi juga 5 kali penerapan, teknik deletion dan teknik amplifikasi masing-masing diterapkan $2 \mathrm{kali}$, dan empat teknik penerjemahan yang menempati urutan terakhir adalah teknik: eksplisitasi, kalke, kreasi diskursif, dan peminjaman alamiah masing-masing diterapkan 1 kali oleh penerjemah.

Dari 13 teknik penerjemahan yang diterapkan penerjemah, 5 teknik penerjemahan bersifat wajib yaitu teknik: peminjaman murni, padanan lazim, deskripsi, adaptasi, dan amplifikasi. Teknik yang bersifat tidak wajib mencakup 12 teknik meliputi teknik: peminjaman murni, padanan lazim, generalisasi, addition, deskripsi, reduksi, adaptasi, deletion, eksplisitasi, kalke, kreasi diskursif, dan peminjaman alamiah. Dari jumlah tersebut dapat disimpulkan bahwa ada 4 teknik yang bersifat wajib dan tidak wajib yaitu teknik peminjaman murni, teknik padanan lazim, teknik deskripsi, dan teknik adaptasi.

Berdasarkan hasil penelitian, ada 9 teknik penerjemahan yang menghasilkan terjemahan akurat meliputi teknik: peminjaman murni, padanan lazim, addition, deskripsi, adaptasi, amplifikasi, generalisasi, kalke, dan peminjaman alamiah. Terjemahan kurang akurat dipengaruhi oleh 5 teknik penerjemahan yaitu teknik: 
peminjaman murni, generalisasi, reduksi, eksplisitasi, dan kreasi diskursif. Satu-satunya teknik yang mempengaruhi tidak akuratnya terjemahan tersebut adalah teknik deletion.

Teknik yang mempengaruhi keberterimaan terjemahan bisa dijelaskan sebagai berikut. Berdasarkan urutan penerapan, terjemahan yang berterima dipengaruhi oleh teknik-teknik: peminjaman murni, padanan lazim, generalisasi, addition, deskripsi, adaptasi, amplifikasi, eksplisitasi, kalke, kreasi diskursif, dan peminjaman alamiah. Terjemahan yang kurang berterima terjadi karena pengaruh dari teknik: peminjaman murni, padanan lazim, dan reduksi, sedanglan terjemahan yang tidak berterima dipengaruhi oleh 2 teknik yaitu teknik deletion dan peminjaman murni.

Teknik penerjemahan yang diterapkan oleh penerjemah dalam terjemahan istilah seni dan budaya dalam Kumpulan Abstrak Hasil Penelitian 1990-1991 Sekolah Tinggi Seni Indonesia (STSI) Surakarta ini mencakup 13 teknik yaitu teknik penerjemahan peminjaman murni, padanan lazim, generalisasi, addition, deskripsi, reduksi, adaptasi, deletion, amplifikasi, eksplisitasi, kalke, kreasi diskursif, dan peminjaman alamiah. Hasil penelitian menunjukkan bahwa teknik peminjaman murni merupakan teknik yang paling sering digunakan dan sekaligus sangat mempengaruhi keakuratan terjemahan dengan jumlah 76 kali. Hal itu bisa dipahami karena istilah seni dan budaya merupakan istilah spesifik yang tidak atau belum tentu ada padanannya dalam bahasa sasaran. Oleh karena itu, biasanya penerjemah meminjam langsung istilah dari bahasa sumber. Selain itu, beberapa teknik yang cukup mempengaruhi keakuratan terjemahan ini adalah teknik-teknik padanan lazim, addition, deskripsi, adaptasi, amplifikasi, generalisasi, kalke, dan peminjaman alamiah. Sedangkan teknik-teknik yang membuat terjemahan kurang akurat mencakup teknik-teknik peminjaman murni, generalisasi, reduksi, eksplisitasi, dan kreasi diskursif. Sementara itu satu teknik yang menjadikan terjemahan ini tidak akurat adalah teknik deletion.

Selain mempengaruhi keakuratan terjemahan, teknik peminjaman murni juga mempengaruhi terjadinya terjemahan yang kurang akurat ketika diterapkan bersamasama dengan teknik lain seperti teknik reduksi, kreasi diskursif, ataupun generalisasi seperti contoh berikut ini: 
Tabel 3. Contoh penggabungan teknik peminjaman murni dan generalisasi

\begin{tabular}{|c|c|c|c|c|c|}
\hline Kode & Data & Teknik & $\begin{array}{l}\text { Sifat } \\
\text { Teknik }\end{array}$ & KA & $\mathrm{KB}$ \\
\hline $\begin{array}{l}026 / \mathrm{Bsu} / 2 \\
2\end{array}$ & $\begin{array}{l}\text { Dengan modal ketrampilan dan } \\
\text { bakat menyusun lagu, Mang } \\
\text { Koko selalu mencoba dan } \\
\text { mencoba terus mengadakan } \\
\text { pembaharuan garap baik irama, } \\
\text { garap petikan kecapi, repertoar, } \\
\text { struktur lagu, cara penyajian dan } \\
\text { sebagainya. }\end{array}$ & \multirow{2}{*}{$\begin{array}{l}\text { Peminjaman } \\
\text { Murni, } \\
\text { Generalisasi }\end{array}$} & \multirow{2}{*}{$\begin{array}{l}\text { wajib, } \\
\text { tidak } \\
\text { wajib }\end{array}$} & \multirow[t]{2}{*}{2} & \multirow[t]{2}{*}{3} \\
\hline $\begin{array}{l}026 / \mathrm{Bsa} / 1 \\
1\end{array}$ & $\begin{array}{l}\text { Mang Koko used his talent and } \\
\text { skills as a composer to bring } \\
\text { about innovations in kecapi } \\
\text { playing, in garap and rhythm, } \\
\text { repertoire, melodic structure, } \\
\text { performance-style and so on. }\end{array}$ & & & & \\
\hline
\end{tabular}

Dalam contoh tersebut, penerjemahan istilah garap petikan kecapi menjadi kecapi playing menggunakan dua teknik sekaligus yaitu peminjaman murni dan generalisasi. Terjemahan ini menjadi kurang akurat karena ada istilah yang digeneralisasi yaitu petikan menjadi playing. Dalam Kamus Besar Bahasa Indonesia (KBBI) disebutkan bahwa petikan kecapi artinya membunyikan kecapi dengan menggamit senar atau dawainya, sedangkan playing, dalam Oxford Advanced Learner's Dictionary of Current English mempunyai makna yang lebih luas yaitu perform on (a musical instrument); perform (music); cause music to be heard (by operating a recordplayer or tape-recorder).

Disisi lain, teknik peminjaman murni akan menghasilkan terjemahan yang akurat bila digabungkan dengan teknik-teknik seperti deskripsi, adaptasi, padanan lazim, atau addition misalnya:

Tabel 4. Contoh penggunaan teknik peminjaman murni dan deskripsi

\begin{tabular}{|l|l|l|l|l|l|}
\hline Kode & Data & Teknik & $\begin{array}{l}\text { Sifat } \\
\text { Teknik }\end{array}$ & KA & KB \\
\hline \hline & $\begin{array}{l}\text { Angsel merupakan garap } \\
\text { khusus, yang biasanya } \\
\text { berfungsi sebagai variasi atau } \\
\text { tekanan-tekanan, untuk } \\
\text { 002/Bsu/01 } \\
\text { menghidupkan suasana } \\
\text { garapan, memantapkan } \\
\text { gerakan tari pada saat angsel, } \\
\ldots\end{array}$ & $\begin{array}{l}\text { Peminjaman } \\
\text { Murni, } \\
\text { Deskripsi }\end{array}$ & $\begin{array}{l}\text { wajib, } \\
\text { tidak } \\
\text { wajib }\end{array}$ & 3 & 3 \\
& & & & \\
\hline
\end{tabular}




\begin{tabular}{|l|l|l|}
0 & $\begin{array}{l}\text { Angsel is a special kind of } \\
\text { garap (the treatment or } \\
\text { working of the music)and is } \\
\text { usually used as a variation or } \\
\text { to emphasize or bring the } \\
\text { music to life at certain points. }\end{array}$
\end{tabular}$|\quad| \quad|\quad| \quad|\quad| \quad|\quad| \quad|\quad| \quad \mid$

Penggabungan antara teknik peminjaman murni dan deskripsi menghasilkan terjemahan yang akurat. Hal itu bisa terjadi karena istilah dari bahasa sasaran dipinjam kemudian dideskripsikan maknanya sehingga pesan dari bahasa sumber tetap tersampaikan sehingga terjemahan yang dihasilkan akurat dan berterima.

Dalam hal keberterimaan terjemahan, penelitian ini menunjukkan bahwa teknik peminjaman murni masih mendominasi teknik-teknik yang lain dalam mempengaruhi keberterimaan terjemahan meskipun teknik ini juga mempengaruhi terjadinya terjemahan yang kurang berterima sekaligus juga terjemahan yang tidak berterima. Beberapa teknik yang juga ikut mempengaruhi terjemahan yang berterima dalam penelitian ini adalah teknik-teknik padanan lazim, generalisasi, addition, deskripsi, adaptasi, amplifikasi, eksplisitasi, kalke, kreasi diskursif, dan peminjaman alamiah. Sedangkan teknik-teknik yang mempengaruhi terjemahan yang kurang berterima meliputi teknik peminjaman murni, padanan lazim, dan reduksi. Sementara itu yang mempengaruhi tidak berterimanya terjemahan dalam penelitian ini adalah teknik deletion dan peminjaman murni.

Teknik penerjemahan mempunyai sifat wajib dan tidak wajib dalam penerapannya. Penelitian ini menyangkut data tentang istilah seni dan budaya yang merupakan istilah spesifik yang seringkali bahkan tidak ada padanannya dalam bahasa sasaran. Oleh sebab itu, penerjemah meminjam istilah dari bahasa sumber agar terjemahannya akurat dan hal itu dilakukan dengan menerapkan teknik peminjaman murni, sehingga teknik ini bersifat wajib digunakan. Meskipun demikian, teknik peminjaman murni juga bersifat tidak wajib ketika istilah budaya yang diterjemahkan mempunyai padanan dalam bahasa sasaran seperti contoh berikut ini: 
Tabel 5. Contoh sifat wajib dan tidak wajib teknik peminjaman murni

\begin{tabular}{|l|l|l|l|l|l|}
\hline Kode & Data & Teknik & Sifat Teknik & KA & KB \\
\hline \hline 009/Bsu/05 & $\begin{array}{l}\text { Setelah proses transkripsi dari kaset } \\
\text { ke dalam bentuk notasi selesai, } \\
\text { bahan ini diidentifikasi dan } \\
\text { diklasifikasi menurut kesamaan } \\
\text { laras dan pathetnya, ... }\end{array}$ & $\begin{array}{l}\text { Peminjaman } \\
\text { Murni, } \\
\text { Addition }\end{array}$ & $\begin{array}{l}\text { Tidak } \\
\text { Wajib, } \\
\text { Tidak Wajib }\end{array}$ & 3 & 3 \\
\hline 009/Bsa/10 & $\begin{array}{l}\text { After the transcription process was } \\
\text { finished, the material was identified } \\
\text { and classified according to laras } \\
\text { (tuning) and pathet (mode). }\end{array}$ & & & & \\
\hline
\end{tabular}

Istilah laras tidak harus dipinjam dalam penerjemahan karena sudah ada tuning yang memiliki kesamaan arti. Oleh karena itu, teknik peminjaman murni tidak wajib diterapkan dan cukup dengan padanan lazimnya tuning. Beberapa teknik yang bersifat wajib dan tidak wajib selain peminjaman murni adalah teknik padanan lazim, deskripsi, dan adaptasi.

Teknik penerjemahan bersifat wajib apabila teknik tersebut memang harus digunakan demi untuk menghasilkan terjemahan yang akurat atau berterima. Tetapi seringkali, penerjemahan dengan hanya menggunakan satu teknik wajib ataupun tidak wajib tidak bisa menghasilkan terjemahan yang akurat sekaligus berterima. hasil dari penerjemahan tersebut, kadang-kadang, bisa akurat saja atau berterima saja jadi tidak bisa keduanya. Oleh sebab itu, penerjemah bisa menggabungkan dua teknik sekaligus. Berikut adalah contoh penggunaan teknik yang bersifat wajib:

Tabel 6. Contoh teknik penerjemahan yang bersifat wajib

\begin{tabular}{|l|l|l|l|l|l|}
\hline Kode & Data & Teknik & Sifat Teknik & KA & KB \\
\hline \hline 003/Bsu/01 & $\begin{array}{l}\text { f., juga bisa sebagai tanda peralihan, } \\
\text { tanda berhenti sesaat ataupun tanda } \\
\text { suwuk. }\end{array}$ & $\begin{array}{l}\text { Peminjaman } \\
\text { Murni }\end{array}$ & wajib & 3 & 2 \\
\hline 003/Bsa/08 & $\begin{array}{l}\text { It may also be used to signal a } \\
\text { transition or as a suwuk signal to } \\
\text { end the piece. }\end{array}$ & & & & \\
\hline
\end{tabular}

Dari contoh tersebut bisa dijelaskan bahwa penggunaan teknik yang bersifat wajib tidak selalu menghasilkan terjemahan yang akurat sekaligus berterima. contoh tersebut menunjukkan hasil terjemahan yang akurat tetapi kurang berterima. hal ini 
terjadi karena suwuk merupakan istilah spesifik yang tidak ada padanannya dalam bahasa sasaran sehingga penerjemah harus menggabungkan dengan teknik lain yang dalam hal ini bisa dengan teknik deskripsi. Hal itu harus dilakukan untuk menghasilkan terjemahan yang akurat dan berterima.

Teknik penerjemahan bersifat tidak wajib artinya bahwa dalam menerjemahkan istilah seni dan budaya tidak harus menggunakan teknik tersebut karena ada teknik lain yang bisa dijadikan pilihan dan semua itu dilakukan untuk mendapatkan suatu terjemahan yang akurat dan berterima. Berikut ini adalah contoh teknik yang tidak wajib digunakan:

Tabel 7. Contoh teknik penerjemahan yang bersifat tidak wajib

\begin{tabular}{|l|l|l|l|l|l|}
\hline Kode & Data & Teknik & $\begin{array}{l}\text { Sifat } \\
\text { Teknik }\end{array}$ & KA & KB \\
\hline \hline 013/Bsu/09 & $\begin{array}{l}\text { Pendokumentasian karya-karya } \\
\text { tersebut di atas dirasa sangat perlu } \\
\text { mengingat karya-karya tersebut } \\
\text { mempunyai rasa musical dan } \\
\text { warna tersendiri dibandingkan } \\
\text { dengan karya-karya empu } \\
\text { lainnya. }\end{array}$ & Generalisasi & tidak wajib & 2 & 3 \\
\hline 013/Bsa/12 & $\begin{array}{l}\text { This documentation was felt to be } \\
\text { of great importance, remembering } \\
\text { that Sunarto Ciptosuwarso's } \\
\text { works have a highly individual } \\
\text { musicality and colour compared } \\
\text { with the works of other great } \\
\text { masters. }\end{array}$ & & & & \\
\hline
\end{tabular}

Teknik generalisasi tidak wajib digunakan karena penerjemah bisa menggunakan teknik peminjaman murni jadi istilah empu tetap dipinjam dalam terjemahan. Terjemahan istilah tersebut tidak akurat dengan menggunakan teknik generalisasi tetapi berterima. Untuk mendapatkan terjemahan yang akurat dan berterima maka penerjemah bisa menerapkan kedua teknik tersebut yaitu peminjaman murni dan generalisasi. Selain pasangan kedua teknik tersebut, beberapa pasangan teknik penerjemahan bisa diterapkan untuk menghasilkan terjemahan istilah seni dan budaya yang akurat dan berterima.

Pada dasarnya, penerjemahan istilah spesifik (seni dan budaya) akan menghasilkan terjemahan yang akurat dengan meminjam istilah bahasa sumber dengan teknik peminjaman baik murni maupun alamiah, tetapi hasil terjemahan belum tentu berterima. Untuk mendapatkan kualitas terjemahan yang akurat dan berterima maka 
penerjemah perlu mencari pilihan teknik lain untuk dipasangkan dengan teknik peminjaman. Beberapa pasangan yang bisa diterapkan misalnya teknik peminjaman dengan padanan lazim, peminjaman dengan deskripsi, peminjaman dengan generalisasi, peminjaman dengan addition, atau peminjaman dengan adaptasi.

Berdasarkan proses analisis yang meliputi analisis domain, analisis taksonomi, dan analisis komponensial maka peneliti berusaha menyimpulkan tema budaya dalam penelitian ini. Dari analisis komponensial diperoleh temuan bagaimana hubungan antara istilah seni dan budaya, teknik penerjemahan yang digunakan dengan kualitas terjemahan yang meliputi keakuratan pesan dan keberterimaan. "Tema budaya terdiri atas sejumlah simbol yang dihubungkan oleh hubungan yang mempunyai makna." (Spradley, 1997:251).

Dalam penelitian tentang analisis teknik dan kualitas terjemahan istilah seni dan budaya yang terdapat dalam Kumpulan Abstrak Hasil Penelitian 1990-1991 Sekolah Tinggi Seni Indonesia (STSI) Surakarta, peneliti melihat adanya penggunaan teknik penerjemahan peminjaman murni dengan persentase paling tinggi dibandingkan dengan teknik yang lain yaitu sejumlah 81 kali dari keseluruhan 172 kali penerapan atau $47 \%$. Teknik peminjaman murni adalah teknik yang sangat mempengaruhi keakuratan terjemahan dan hasil analisis menunjukkan bahwa 54 dari 81 data tersebut tergolong terjemahan yang berterima. hal itu terjadi karena teknik ini diterapkan bersama-sama dengan teknik yang lain seperti padanan lazim, generalisasi, addition, deskripsi, kalke, dan kreasi diskursif. Teknik-teknik tersebut adalah teknik yang memberi pengaruh terhadap keberterimaan terjemahan. Oleh karena itu dapat disimpulkan bahwa untuk mendapatkan hasil terjemahan istilah seni dan budaya Indonesia (khususnya Jawa) yang akurat dan berterima, penerjemah seharusnya menggunakan teknik peminjaman murni bersama-sama dengan teknik lain yang mempengaruhi keberterimaan terjemahan seperti padanan lazim, generalisasi, addition, deskripsi, dan sebagainya.

Penelitian ini juga menganalisis tentang sifat wajib dan tidak wajib dari teknik penerjemahan yang diterapkan penerjemah dalam terjemahan istilah seni dan budaya dalam Kumpulan Abstrak Hasil Penelitian 1990-1991 Sekolah Tinggi Seni Indonesia (STSI) Surakarta. Suatu teknik penerjemahan wajib digunakan apabila istilah yang diterjemahkan tidak mempunyai padanan dalam bahasa sasaran seperti istilah seni dan budaya (istilah spesifik). Suatu teknik penerjemahan tidak wajib digunakan apabila 
istilah bahasa sumber bisa diterjemahkan dengan menggunakan teknik lain. Pada dasarnya, sifat wajib dan tidak wajib teknik penerjemahan bertujuan untuk menghasilkan terjemahan yang akurat dan berterima. Berikut ini adalah contohnya:

Tabel 8. Contoh teknik penerjemahan yang bersifat wajib

\begin{tabular}{|l|l|l|l|l|l|}
\hline Kode & Data & Teknik & Sifat Teknik & KA & KB \\
\hline \hline 044/Bsu/14 & $\begin{array}{l}\text { Kesenian topeng Panji diilhami } \\
\text { karya sastra Panji, demikian juga } \\
\text { nilai simbolismenya disesuaikan } \\
\text { dengan } \text { wanda dan pakem yang ada. }\end{array}$ & Peminjaman \\
044/Bsa/16 & $\begin{array}{l}\text { Murni } \\
\text { inspired by the literary works of } \\
\text { Panji, as were its symbolic values } \\
\text { which are true to the existing Wanda } \\
\text { and } \text { Pakem. }\end{array}$ & wajib & 3 & 2 \\
\hline
\end{tabular}

Contoh tersebut menunjukkan bahwa teknik peminjaman murni wajib diterapkan karena istilah pakem yang merupakan istilah budaya tidak ada padanannya dalam bahasa sasaran sehingga harus dipinjam. Hal itu dilakukan untuk mempertahankan keakuratan terjemahan tetapi memang teknik ini menjadikan terjemahan kurang berterima karena istilah tersebut tidak ada padanannya.

Tabel 9. Contoh teknik penerjemahan yang bersifat tidak wajib

\begin{tabular}{|l|l|l|l|l|l|}
\hline Kode & Data & Teknik & Sifat Teknik & KA & KB \\
\hline \hline 009/Bsu/05 & $\begin{array}{l}\text { Setelah proses transkripsi dari kaset } \\
\text { ke dalam bentuk notasi selesai, } \\
\text { bahan ini diidentifikasi dan } \\
\text { diklasifikasi menurut kesamaan } \\
\text { laras dan pathetnya, }\end{array}$ & $\begin{array}{l}\text { Peminjaman } \\
\text { Murni, } \\
\text { Addition }\end{array}$ & $\begin{array}{l}\text { Tidak } \\
\text { Wajib, } \\
\text { Tidak Wajib }\end{array}$ & 3 & 3 \\
\hline 009/Bsa/10 & $\begin{array}{l}\text { After the transcription process was } \\
\text { finished, the material was identified } \\
\text { and classified according to laras } \\
\text { (tuning) and pathet (mode) }\end{array}$ & & & & \\
\hline
\end{tabular}

Contoh tersebut menunjukkan bahwa teknik peminjaman murni bersifat tidak wajib karena istilah laras sebenarnya mempunyai padanan dalam bahasa sasaran yaitu tuning, sehingga penerjemah bisa menggunakan teknik addition. Namun kedua teknik tersebut diterapkan oleh penerjemah karena ingin membuat terjemahannya akurat dan berterima. 
Dari beberapa contoh di atas dapat disimpulkan bahwa sifat wajib dan tidak wajib teknik penerjemahan juga mempengaruhi kualitas terjemahan dalam hal ini keakuratan dan keberterimaan.

\section{SIMPULAN}

Berdasarkan analisis dan pembahasan tentang teknik penerjemahan, sifat teknik penerjemahan, dan kualitas terjemahan yang mencakup keakuratan dan keberterimaan dalam terjemahan istilah seni dan budaya dalam Kumpulan Abstrak Hasil Penelitian 1990-1991 Sekolah Tinggi Seni Indonesia (STSI) Surakarta, maka diperoleh simpulan sebagai berikut:

Berdasarkan analisis terhadap 112 data terdapat 13 teknik penerjemahan yang diterapkan oleh penerjemah. Teknik peminjaman murni mendominasi urutan berdasarkan jumlah data yaitu 81 data atau $48 \%$, setelah itu menyusul teknik padanan lazim 30 data (17\%), generalisasi 16 data (9\%), addition 14 data (8\%), dan deskripsi 13 data (7.5\%). Teknik-teknik tersebut yang sering diterapkan penerjemah dalam terjemahan ini sedangkan teknik lain yang juga diterapkan meliputi teknik reduksi dengan jumlah data $5(3 \%)$, adaptasi 5 data (3\%), kemudian teknik deletion dan amplifikasi masing-masing dengan 2 data (1.16\%), selanjutnya eksplisitasi, kalke, kreasi diskursif dan peminjaman alamiah masing-masing 1 data $(0.6 \%)$.

Dari hasil analisis diketahui bahwa dari ketigabelas teknik penerjemahan yang telah ditemukan dalam penelitian ini ada beberapa teknik yang bersifat wajib, ada yang tidak wajib, dan ada yang bersifat wajib sekaligus tidak wajib. Teknik yang bersifat wajib mencakup peminjaman murni, padanan lazim, deskripsi, adaptasi, dan amplifikasi sedangkan teknik yang bersifat tidak wajib meliputi teknik peminjaman murni, padanan lazim, generalisasi, addition, deskripsi, reduksi, adaptasi, deletion, eksplisitasi, kalke, kreasi diskursif, dan peminjaman alamiah. Apabila pernyataan tersebut diperhatikan, dapat diketahui bahwa beberapa teknik mempunyai sifat wajib dan tidak wajib yaitu peminjaman murni, padanan lazim, deskripsi, dan adaptasi.

Secara umum, tingkat keakuratan dan keberterimaan terjemahan istilah seni dan budaya dalam Kumpulan Abstrak Hasil Penelitian 1990-1991 Sekolah Tinggi Seni Indonesia (STSI) Surakarta termasuk tinggi. Dari hasil kuesioner terhadap 112 data diketahui bahwa dalam hal keakuratan, data yang tergolong dalam terjemahan akurat 
berjumlah 99 data (88\%), kurang akurat sebanyak 11 data (10\%), dan tidak akurat 2 data $(2 \%)$. Sedangkan untuk keberterimaan, data yang tergolong dalam terjemahan berterima berjumlah 97 data (87\%), data yang diterjemahkan secara kurang berterima sebanyak 13 data (11\%), dan data yang tergolong dalam terjemahan tidak berterima berjumlah 2 data $(2 \%)$.

\section{DAFTAR PUSTAKA}

Machali, R. (2000). Pedoman bagi penerjemah. Jakarta: PT Grasindo.

Melis, N.M., \& Amparo H.A. (2001). Assessment in Translation Studies: Research Needs, Meta 46(2).

Molina, L., \& Albir, A.H. (2002). Translation Techniques Revisited: A Dynamic and Functionalist Approach. Jurnal Meta. Vol.XLVII, No.4

Nababan, M.R. (1999). Teori menerjemah bahasa Inggris. Yogyakarta: Pustaka Pelajar

Nababan, M.R. (2008). Kompetensi penerjemahan dan dampaknya pada kualitas terjemahan. Pidato Pengukuhan Guru Besar Penerjemahan Pada Fakultas Sastra dan Seni Rupa Universitas Sebelas Maret.

Nababan, M.R., et al. (2012). Pengembangan Model Penilaian Kualitas Terjemahan dalam Kajian Linguistik dan Sastra, Vol. 24, No. 1, Juni 2012: 39-57

Newmark, P. (1998). A textbook of translation. New York London: Prentice Hall.

Sakri, A. (1985). Ihwal menerjemahkan. Bandung: ITB.

Spradley, J.P. (1997). Metode etnografi. Yogyakarta: PT Tiara Wacana.

Sutopo, H.B. (2006). Metodologi penelitian kualitatif: dasar teori dan terapannya dalam penelitian. Surakarta: UNS Press. 